\title{
PRINCIPLES OF CREATING HYBRID INTEGRATED AUTOMATED SYSTEMS OF TECHNOLOGICAL PROCESS DESIGN AND CONTROL
}

\author{
G.B. Burdo ${ }^{1}$, Dr.Sc. (Engineering), Head of Chair, gbtms@yandex.ru \\ N.A. Semenov 1, Dr.Sc. (Engineering), Professor, slt1155@mail.ru
}

${ }_{1}^{1}$ Tver State Technical University, Nikitin Quay 22, Tver, 170026, Russian Federation

\begin{abstract}
It is known that domestic and foreign machine building industry have been affected by serious structural changes over the past few years. Their main point is that the part of single piece and small-lot machinery production (multiproduct engineering manufacture, MM) is up to 25-30 per cent in the total amount of machine building industry products. However, the problems of automated technological process design and automated production control are solved in the indicated production types. This is due to the fact that multiproduct machinery production systems stand out for high acceleration capacity. Moreover, transfer of batch production experience leads to significant delay of a control action and its incorrectness, and designed technologies don't count a production system state.

The bailout plan is possible in the case of information integration of technological process design automation systems and automated technological process control systems. In this regard automated technological process control systems must provide a possibility to correct production plans at all levels quickly.

The paper shows relevance of the proposed concept of information integration of automated systems of technological process design and control in a multiproduct manufacture. The research is based on the system theory framework and the product life cycle methodology. The authors examine the hierarchy of the systems and explain the principles of creating integrated systems and their subsystems. They also suggest the decision-making method for technological process design and control in hybrid systems.
\end{abstract}

Keywords: machine-building multiproduct manufacture, automated technological process control system, automated technological process design, hybrid systems.

It is known that domestic and foreign machine building industry have been affected by serious structural changes over the past few years. Their main point is that the part of single piece and small-lot machinery production (multiproduct engineering manufacture, $\mathrm{MM}$ ) is up to $25-30$ per cent in the total amount of machine building industry products. This is due to the natural consumers' desire to have goods with the properties they need at the right time. Besides, most enterprises in breakthrough machine building industry directions produce the first samples of science-intensive, high-technology products in small batches.

Multiproduct manufacture is characterized by a large number of simultaneous orders, high dynamism of a production situation in technological units, constant (all year round) emergence of new contracts with tough deadlines. Unfortunately, due to its small amount earlier, multiproduct manufacture was away from a range of problems, as well as from industrial developments in technological process design automation systems (TP DAS) and automated technological process control systems (APCS). This fact determines low efficiency of designed technologies due to the lack of time for manufacturing preparation. It also creates problems in technological process control and eventually increases new product preparation time and product manufacturing production run.

The bailout plan is the information integration of TP DAS and APCS based on the principles suggested below.

\section{Principles of creating integrated TP DAS and APCS}

The papers [1-4] consider set-theoretic models of integrating APCS and TP DAS. These works also show the types of information transformations, system hierarchy, the rules of the synthesized decisions selection.

In order to take into account multiproduct manufacture peculiarities, these papers formulate the principles determining creating of integrated TP DAS and APCS (IS). Let us have a closer look at them.

1. Information integration has to provide the minimum industrial system lag effect determined by the time of response to a production situation change. This requirement is dictated by the need to ensure industrial system functioning according to the "just-in-time" principle [5].

2. The integrated system has to make product life cycle control possible.

3 . The integrated system has to work within a product quality control system.

4. The integrated system has to be controlled by the enterprise control system (ECS) based on direct communication and feedback, have external information relations with the designing preproduction system; controlled objects are industrial system workplaces.

5. TP DAS and APCS interaction has to be as follows. TP DAS information (machining content, tracks of parts going through workplaces) is APCS input information. At the same time, this information synthesis takes into account the data on the actual industrial system state received from APCS (feedback). Thus, it cre- 
ates a background for effective control at the technological process design stage.

\section{Principles of creating TP DAS within integrated systems}

The principles considered below are based on the understanding that the difference between design-engineering parts characteristics; various equipment structure and jigs, fixtures and tools; unpredictable conditions of technological machine load units, the actual number of workers, new orders emergence, etc. predetermine the interpretation of a technology development process as an insufficiently formalized, multiplechoice organizational and technological task, which is solved in the context of information uncertainty $[4,6]$. There are following principles:

- taking into account a current situation in machine load production units;

- subordinating the technological processes (TP) objective to the firm objectives when fulfilling a concrete order;

- fast response time of manufacturing preparation processes;

- creating prerequisites for effective technological process design;

- creating prerequisites for effective technological process control at the technological process design stage;

- the hierarchical organization of TP DAS Procedures

- the system has to provide the hybrid work mode.

Let us now characterize the principles listed.

The meaning of the first principle is to assign process operations to currently least busy workplaces.

The meaning of the second principle is to set the objective $(O)$ for technological processes designed for a given order.

The third principle is about available operative information communications: a) between the units responsible for manufacturing preparation (MP) and the technological process control system (the equipment workload data); b) between the units responsible for MP and ECS (the order objective type).

It is rational to create prerequisites for effective technological process design when controlling designing preproduction processes. For this purpose, there should be certain measures for product design unification, which leads to engineering process unification and determines the possibility to implement advanced technologies on up-to-date equipment. This will ensure the reduction of design procedure labor input, the improvement of design decisions quality due to the optimization of technology elements for standard parts and their surfaces.

Creating prerequisites for effective technological process control at the technological process development stage means subordinating design purposes to in- dustrial system purposes in the context of contract implementation terms, as well as technological units debottlenecking (see also principles 2 and 3 ).

Hierarchical organization of procedures means organizing design flow using the decomposition method. It is natural for human reasoning and allows experts to estimate results in their natural state.

The hybrid way is based on the following. Several feasible solutions are generated at each level of TP DAS design decomposition. After that, based on his experience and intuition the designer estimates and selects one or several rational solutions for subsequent detailing. This is due to the fact that decisions at the top decomposition levels cannot always be estimated by clear parameters (production costs, productivity, etc.). The top level involves choosing one decision.

A special focus should be on deciding on the type of a technological process objective. In this case, a group of experts (enterprise engaged services workers) make an agreed decision according to a certain algorithm [7].

\section{Principles of creating APCS within integrated systems}

Modern trends of machine building industry development $[8,9]$ include total quality control (TQC) or total quality management (TQM), total equipment maintenance (TEM), and a "just-in-time" product system (JIT).

These components ensure creating lean production that involves manufacturing in timeframes specified by ECS and work in progress with minimum expenses.

The JIT system depends on APCS that has to make decisions aimed at reducing the overall production cycle.

Adhering to the principles should ensure semantic unity of AS TPC procedures planning and control processes.

The first principle of creating APCS is the principle of system unity and interconnection. This involves considering all APCS agents individually and allows identifying APCS as an independent entity that preserves integrity properties.

The second principle of creating APCS is making plan hierarchy and control accuracy correspond to enterprise plan accuracy. According to the system approach, the accuracy principle means that plan accuracy should increase as plans become more detailed.

The third principle of creating APCS is control continuity due to the feedback from ECS and technological units (TU), and efficiency due to AI elements. Control decisions should be made with the minimum allowable response time. The APCS allowable response time determines the interval of detecting plan unbalance (feedback) and computation execution speed.

The fourth principle of creating APCS is securing plan reserves. Reserves are necessary for the plans developed by APCS. Calculation algorithms should in- 
clude evaluation of a situation in technological units. This means a wide scheduling (WS) agent in APCS to build technological units margin power into calendars and schedules (CS). When determining reserves it should be noted that they cannot be too large, otherwise plans will be inaccurate. At the same time, too small reserves will cause frequent changes in company plans in general, which erodes control points in company operations.

The fifth principle of creating APCS says that APCS should plan an interactive hybrid mode with human involvement into the management process and additional management resources acquisition. APCS planning and management has several stages: wide scheduling, scheduling, operational planning and manual supervision (management). The first three stages are iterative. At each iterative stage and after stage completion the system offers possible decisions. The group of experts analyzes and evaluates them. At the manual supervision stage, experts analyze and evaluate possible managing decisions at the end of each operational planning interval. The most rational decision is made using fuzzy sets [10-12].

The sixth principle of creating APCS is complexity, i.e. considering the most important factors that influence control problems in their interrelation, as well as evaluating interrelation ща decisions. This principle considers the task of TP control more broadly, to begin with creating APCS effective work prerequisites using a number of principles when creating technological units, timing production startup processes and maintaining control via TP DAS.

\section{Conditions of implementing the suggested approaches to IS creation}

New ways of industrial system control are impossible to introduce without fulfilling a number of conditions for successful implementation of the project.

1. Priority of work.

A. First, it is rational for engineering-technological service workers to perform operations of technological design unification.

B. Along with the abovementioned, it is possible to balance production facilities. It should be noted that work listed in A and B is to be regular.

C. Developing of mechanisms for manufacturing preparation management aimed at industrial system operation cycle reduction due to simultaneous performing work at the joint of the following stages: (a) designing preproduction - manufacturing preparation, and (b) manufacturing preparation - organizational and managerial preproduction.

D. Introducing of the concept of technological process organizational and technological designing. Surprisingly, the main difficulty in its implementation is to accustom the head of a company industrial system to clearly and accurately formulate a target designation when fulfilling an order, which points a TP objective.
The second difficulty is the need to systematically monitor machine load, which adds some work to the monitoring service.

2. Training shop management personnel, especially line crew and operations control heads. The role of this group in multiproduct manufacture is very important, therefore their skill requirements are enormously high. They have to be able to make managerial decisions. The main task of personnel training is to teach them manufacturing production run and production facilities control as in practice there are no suitable shopfloor automation control systems like the SCADA system for multiproduct manufacture.

3. Training engineering-technological services personnel. The aim is to teach them process design according to an objective, not intuition, to teach them the basics of production management.

4. The phase-in of integrated information automated systems for technological process design, CNC control software development and technological process control. This will considerably improve decision efficiency. For small enterprises (up to 100-150 direct workers) it is possible to develop a special compact system.

5. An enterprise head's readiness to invest not only into production facilities development and into modernization, but also into workers' further training.

6. The last and perhaps most difficult task is to make all those involved into a production process (designers, engineers, shop management personnel, workers) feel corporate responsibility. Practice shows that here it is impossible to do without forming a certain corporate culture and using worker encouragement methods, not punishment.

\section{Result discussion}

As it can be seen, the paper has three main points: 1) reducing response time (from the point of time factor) when making decisions in a developed integrated automated system; 2) improving the quality of the decisions made and their compliance to production conditions; 3 ) ensuring the achievement of a single global goal in pre-production engineering and technological process control.

The experience of multiproduct manufacture industrial system shows that the time for developing technological process and preparing control programs for machine tools with numerical program control should be reduced by factor of 3-4 comparing with serial manufacturing. Increasing the number of engineers of this level is not the best way to solve the task. Therefore, the approach suggested in the paper with its aim to intellectualize engineering work seems the most effective way to increase its productivity.

Along with the availability of information connection with an automated control system, it will allow increasing and maintaining appropriate designed technologies quality due to the availability of training and 
design elements, taking into account the current situation in production units. At the same time, due to the use of less loaded equipment for technological process realization, there are prerequisites for effective production work.

In multiproduct science-intensive machine building and instrument making, master production schedules for the next calendar year at the end of a current year are typically formed by $40-60 \%$. The main amount of work (excluding small orders) is known only by $\mathrm{Au}-$ gust or September.

This means being constant engaging in revising calendar plans and schedules. Existing industrial control systems do not allow reacting to plan changes quickly enough, which leads to the growth of management personnel number. The suggested approach is based on informational and algorithmic matching of plans at all levels. It allows automatic searching for capacity reserves starting with local plans and, if necessary, adjusting plans of higher levels.

Taking into account the range of tasks solved by the integrated system, its architecture is service-oriented. This ensures real-time information interaction of various services specialists (technologists, management personnel of various levels, industrial system head) and the involvement of production units' foremen into decision-making procedures.

The unified target designation in an automated system is ensured by the fact that the objective when designing technological processes, as well as order priority when controlling technological processes is determined based on calendar timing of an order and its cost.

\section{Conclusion}

The paper suggests approaches that have all been tested and implemented in phases. They have become a basis for the software that has shown its worth on one of the enterprises of instrument making.

The paper intentionally does not mention such issues as enterprise complex process control, service functional structure optimization, quality management system implementation, contractor work coordination, etc. These tasks concern not only the middle management but the upper executive management as well and often draw workers' protests. Hence, their efficient implementation is usually difficult. It depends on a head's will and is a separate topic.

Acknowledgment. The work has been financially supported by RFBR, project no. 17-01-00566.

\section{References}

1. Burdo G.B., Palyukh B.V. Theoretical basics of complex automated system of technological process designing and management in multiproduct manufacture. Vestn. SamGTU. Ser. Tekhnicheskie nauki [Vestnik of Samara State Tech. Univ. Technical Sciences Series]. 2010, no. 4, pp. 44-54 (in Russ.).

2. Burdo G.B., Palyukh B.V., Semenov N.A. Sistemy upravleniya tekhnologicheskimi protsessami v mashinostroenii: podkhody $k$ sozdaniyu intellektualnykh sistem upravleniya [Control systems of technological processes in mechanical engineering: approaches to the creation of intelligent control systems]. Palmarium Academic Publ., Saarbruchen, Germany, 2012, 287 p.

3. Burdo G.B., Semenov N.A., Isaev A.A. Technological processes control automated system in multiproduct manufactures. Programmnye produkty $i$ sistemy [Software \& Systems]. 2012, no. 1, pp. 80-83 (in Russ.).

4. Burdo G.B. Improving the technological preparations for manufacturing production. Russian Eng. Research, 2017, vol. 37, no. 1 , pp. 49-56.

5. Kapustin N.M. Avtomatizirovannaya sistema proektirovaniya tekhnologicheskikh protsessov [Technological Process Automated System Design]. Moscow, Mashinostroenie Publ., 1979, 287 p.

6. Gavrilov D.A. Upravlenie proizvodstvom na baze standartov MRP-11 [Managing production based on MRP-11 standards]. Saint Petersburg, Piter Publ., 2002, 320 p.

7. Womack J.P., Jones D.T. Lean Thinking. NY, Free Press, 2003,397 p.

8. Shingo Sh. Kaizen and the art of creative thinking. Enna Product Corp. and PCS Inc., 2007, $282 \mathrm{p}$.

9. Shingo S. A study of the Toyota production system from an industrial engineering viewpoint. Portland, Oregon, Productivity Press, $1989,363 \mathrm{p}$.

10. Lee M.H. Model-based reasoning: a principled approach for software engineering. Software - Concepts and Tools, 2000, vol. 19, no. 4, pp. $179-189$.

11. Cooper R. When lean enterprises collide: competing through confrontation. Boston: Harvard Business School Press, $1995,379 \mathrm{p}$.

12. Smirnova N.V. How not to step on the rake during the transition to process management. Production Management, 2009, no. 3, pp. 26-32 (in Russ.)

13. Zadeh L. Fuzzy sets. Information and Control. 1965, no. 8, pp. 338-353.

14. Zadeh L. Fuzzy probabilities. Information Processing and Management, 1984, vol. 3, pp. 363-372.

15. Vasilev V.N. Organizatsiya proizvodstva $v$ usloviyakh rynka [Organization of production in market conditions]. Moscow, Mashinostroenie Publ., 1993, 368 p.

16. Solomentsev Yu.M., Mitrofanov V.G., Pavlov V.V., Rybakov L.V. Informatsionno-vychislitelnye sistemy $v$ mashinostroenii $i$ CALS-tekhnologii [Computing system in engineering and CALStechnologies]. Moscow, Nauka Publ., 2003, 292 p.

17. Prilutsky M.Kh. Multi-criteria multi-index tasks of volumescheduling. Jour. of Computer and Systems Sciences International, 2007, no. 1, pp. 78-82 (in Russ.).

18. Yablochnikov E.I. The organization of a single information space of technical preparation of production using PDM SmarTeam. Informatsionnye technologii v proektirovanii i proizvodstve, 2009, no. 3, pp. 22-29 (in Russ.).

19. Obukhov I.A., Gaifullin B.N. Avtomatizatsiya sistem upravleniya predpriyatiyami standarta ERP-MRP-11 [Automation of enterprises management systems of ERP-MRP-11 standard]. Moscow, Interface-Press Publ., 2002, $286 \mathrm{p}$

20. Balakhonova I.V., Volchkov S.A., Kapiturov V.A. Logistika: integratsiya processov s pomoshchyu ERP-sistemy [Logistics: integration of processes using the ERP system]. Nizhny Novgorod, Prioritet Publ., 2006. 464 p. ПРОЕКТИРОВАНИЯ И УПРАВЛЕНИЯ ТЕХНОЛОГИЧЕСКИМИ ПРОЦЕССАМИ

Г.Б. Бурдо ${ }^{1}$, д.m.н., зав. кафедрой, gbtms@yandex.ru

Н.А. Семенов ${ }^{1}$, д.m.н., профессор, slt1155@mail.ru

${ }^{1}$ Тверской государственньй технический университет, наб. Аф. Никитина, 22, г. Тверь, 170026, Россия 
Аннотация. Известно, что за последние годы отечественное и зарубежное машиностроение затронули серьезные структурные изменения. Основная их суть состоит в том, что в настоящее время доля единичного и мелкосерийного типов машиностроительных производств (многономенклатурного машиностроительного производства, МП) составляет до 25-30 \% в общем объеме продукции машиностроения. Однако вопросы, связанные с автоматизированным проектированием технологических процессов и автоматизированным управлением производством, не решены в указанных типах производств. Это объясняется тем фактом, что производственные системы многономенклатурного машиностроительного производства отличаются высокой динамичностью и перенос опыта использования указанных систем в серийном производстве приводит к значительному запаздыванию управляющего воздействия и его некорректности, а спроектированные технологии не учитывают состояние производственной системы.

Выход из данной ситуации представляется возможным за счет информационной интеграции систем автоматизированного проектирования и управления, при этом автоматизированные системы управления технологическими процессами должны обеспечивать возможность оперативной корректировки производственных планов всех уровней.

В указанных системах должна предполагаться реализация различных моделей (в том числе и с участием человека - эксперта) принятия решений.

Показана актуальность предложенной концепции информационной интеграции автоматизированных систем проектирования и управления технологическими процессами в многономенклатурном производстве (концепции организационно-технологического проектирования). Исследование проведено на основе аппарата теории систем и методологии жизненного цикла изделий. Показана иерархия рассматриваемых автоматизированных систем. Обоснованы принципы создания интегрированных систем и входящих в нее подсистем. Предложена методика принятия решений по проектированию технологических процессов и при управлении ими в гибридных системах.

Ключевые слова: машиностроительное многономенклатурное производство, автоматизированная система управления технологическими процессами, автоматизированное проектирование технологических процессов, гибридные системь.

Благодарность. Работа выполнена при финансовой поддержке РФФИ, проект № 17-01-00566.

\section{Литература}

1. Бурдо Г.Б., Палюх Б.В. Теоретические основы комплексной автоматизированной системы проектирования и управления технологическими процессами в многономенклатурном производстве // Вестн. Самарского гос. технич. ун-та: Технические науки. 2010. № 4. С. 44-54.

2. Бурдо Г.Б., Палюх Б.В., Семенов Н.А. Системы управления технологическими процессами в машиностроении: подходы к созданию интеллектуальных систем управления. Palmarium Acad. Publ., Saarbruchen, Deutschland, 2012, $287 \mathrm{p}$.

3. Бурдо Г.Б., Семенов Н.А., Исаев А.А. Автоматизированная система управления технологическими процессами в многономенклатурных производствах // Программные продукты и системы. 2012. № 1. С. 80-83.

4. Burdo G.B. Improving the technological preparations for manufacturing production. Russian Eng. Research, 2017, vol. 37, no. 1, pp. 49-56.

5. Капустин Н.М. Автоматизированная система проектирования техногогических процессов. М.: Машиностроение, 1979. $287 \mathrm{c}$

6. Гаврилов Д.А. Управление производством на базе стандартов MRP-11. СПб: Питер, 2002. 320 с.

7. Womack J.P., Jones D.T. Lean thinking. NY, Free Press, 2003, 397 p.

8. Shingo S. Kaizen and the art of creative thinking. Enna Product Corporation and PCS Inc., 2007, 282 p.

9. Shingo S. A study of the toyota production system from an industrial engineering viewpoint. Portland, Oregon, Productivity Press, 1989, $363 \mathrm{p}$

10. Lee M.H. Model-based reasoning: A principled approach for software eng. Software - Concepts and Tools, 2000 , vol. 19, no. 4, pp. 179-189. $379 \mathrm{p}$

11. Cooper R. When lean enterprises collide: competing through confrontation. Harvard Business School Press, 1995,

12. Смирнова Н.В. Как не наступить на грабли при переходе на процессное управление // Управление производством. 2009. № 3. С. 26-32.

13. Zadeh L. Fuzzy Sets. Information and Control, 1965, no. 8, pp. 338-353.

14. Zadeh L. Fuzzy probabilities. Information Proc. and Management, 1984, vol. 3, pp. 363-372.

15. Васильев В.Н. Организация производства в условиях рынка. М.: Машиностроение, 1993. 368 с.

16. Соломенцев Ю.М., Митрофанов В.Г., Павлов В.В., Рыбаков Л.В. Информационно-вычислительные системы в машиностроении и CALS-технологии. М.: Наука, 2003. 292 с.

17. Прилуцкий М.Х. Многокритериальные многоиндексные задачи объемно-календарного планирования // Изв. АН: Теория и системы управления. 2007. № 1. С. 78-82.

18. Яблочников Е.И. Организация единого информационного пространства технической подготовки производства с использованием PDM SmarTeam // Информ. технологии в проектировании и производстве. 2009. № 3. C. $22-29$.

19. Обухов И.А., Гайфуллин Б.Н. Автоматизация систем управления предприятиями стандарта ЕRP-MRP-11. М.: Интерфейс-Пресс, 2002. 286 с.

20. Балахонова И.В., Волчков С.А., Капитуров В.А. Интеграция процессов с помощью ЕRР-системы. М.: Приоритет, 2006. $464 \mathrm{c}$. 